

\section{DISCLAIMER}

This report was prepared as an account of work sponsored by an agency of the United States Government. Neither the United States Government nor any agency Thereof, nor any of their employees, makes any warranty, express or implied, or assumes any legal liability or responsibility for the accuracy, completeness, or usefulness of any information, apparatus, product, or process disclosed, or represents that its use would not infringe privately owned rights. Reference herein to any specific commercial product, process, or service by trade name, trademark, manufacturer, or otherwise does not necessarily constitute or imply its endorsement, recommendation, or favoring by the United States Government or any agency thereof. The views and opinions of authors expressed herein do not necessarily state or reflect those of the United States Government or any agency thereof. 


\section{DISCLAIMER}

Portions of this document may be illegible in electronic image products. Images are produced from the best available original document. 
Printed in USA. Price: $\$ 0.50$ Available from the

Office of Technical Services

U. S. Department of Commerce

Washington 25, D. C.

\section{LEGAL NOTICE}

This report was prepared as an account of Government sponsored work. Neither the United States, nor the Commission, nor any person acting on behalf of the Commission:

A. Makes any warranty or representation, expressed or implied, with respect to the accuracy, completeness, or usefulness of the information contained in this report, or that the use of any information, apparatus, method, or process disclosed in this report may not infringe privately owned rights; or

B. Assumes any liabilities with respect to the use of, or for damages resulting from the use of any information, apparatus, method, or process disclosed in this report.

As used in the above, "person acting on behalf of the Commission" includes any employee or contractor of the Commission, or employee of such contractor, to the extent that such employee or fontractor of the Commission, or employee of such contractor prepares, disseminates, or provides access to, any information pursuant to his employment or contract with the Commission, or his employment with such contractor. 
ORNL-3554

vC 20 - Controlled Thermonuctear Processes

Contract No. W-7405-eng-26

$$
\begin{aligned}
& \text { UC-28 fartude fecelenatos } \\
& \text { and thigh-Voltage }
\end{aligned}
$$

ELECTRONUCLEAR DIVISION

\section{A FORTRAN PROGRAM FOR ESTIMATING RESIDUAL RADIATION LEVELS IN HIGH-ENERGY CHARGED-PARTICLE ACCELERATORS}

J. B. Ball and C. B. Fulmer

MARCH 1964

OAK RIDGE NATIONAL LABORATORY

Oak Ridge, Tennessee

operated by

UNION CARBIDE CORPORATION

for the

U. S. ATOMIC ENERGY COMMISSION 


\section{THIS PAGE}

\section{WAS INTENTIONALLY LEFT BLANK}




\section{CONTENTS}

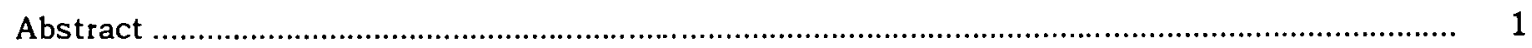

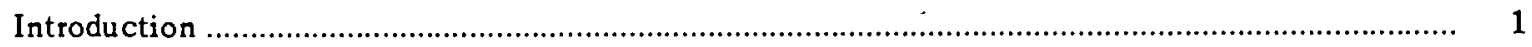

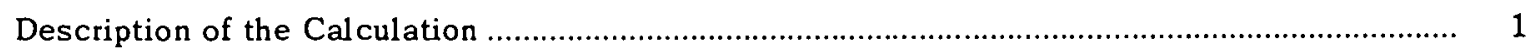

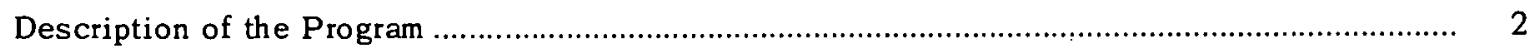

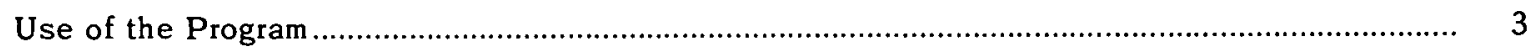

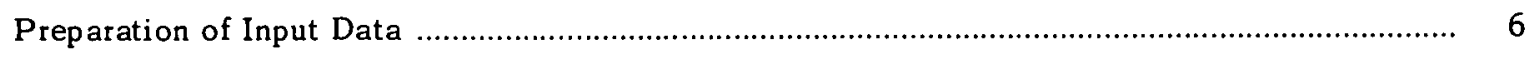

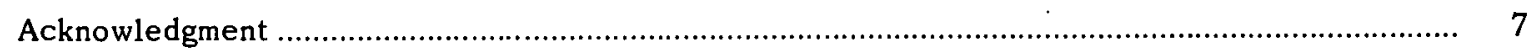

Appendix I - FORTRAN Listing for Main Program ............................................................

Appendix II - FORTRAN Listing for AINT Function .......................................................... 12 


\title{
A FORTRAN PROGRAM FOR ESTIMATING RESIDUAL RADIATION LEVELS IN HIGH-ENERGY CHARGED.PARTICLE ACCELERATORS
}

\author{
J. B. Ball and C. B. Fulmer
}

\begin{abstract}
A FORTRAN II program is described for utilizing cross-section data for spallation. products to obtain an estimate of the residual radiation from the bombardment of materials with high-energy particles.
\end{abstract}

\section{INTRODUCTION}

In the course of studying the feasibility of a high-intensity charged-particle accelerator, it is desirable to make a realistic appraisal of the radiation levels that will result from operation of the machine. Such an appraisal will help to ascertain the gamma shielding and remote handling facilities needed for safe operation and maintainance of the machine and associated experimental equipment. Expenditures for unnecessary facilities can thus be kept at a minimum without incurring unanticipated delays in maintainance operations due to high levels of residual radiation.

Calculation of residual radiation levels for a given spallation product as a function of incident beam intensity, bombardment time, and cooling time is straightforward. The total residual radiation level results, however, from the contributions of all the spallation products, and thus the amount of computation becounes prohibitively time consuming for hand calculation. This report describes a computer program that was prepared and used in residual radiation studies for the proposed ORNL $\mathrm{Mc}^{2}$ Cyclotron, which is designed to accelerate $100 \mu \mathrm{a}$ of protons to an energy of $810 \mathrm{Mev}$.

\section{DESCRIPTION OF THE CALCULATION}

It is assumed that a collimated beam of particles impinges normally on a slab of material. The incident beam intensity $I_{0}$ is attenuated in the material by the macroscopic geometric cross section $\Sigma$. Thus at a depth $X$ in the slab,

$$
I(X)=I_{0} \exp \left(-\Sigma_{t} X\right)
$$

The production rate of spallation product $j$ at position $X$ is

$$
R_{j}(X)=I(X) \Sigma_{j}
$$


where $\Sigma_{j}$ is the macroscopic cross section for the reaction. After bombardment time $t_{B}$ and cooling time $t_{c}$, the concentration of product $j$, as a function of $X$, is

$$
N_{j}(X)=\left\{R_{j}(X)\left[1-\exp \left(-\lambda_{j} t_{B}\right)\right] \exp \left(-\lambda_{j} t_{c}\right)\right\} / \lambda_{j},
$$

where $\lambda_{j}$ is the radioactive decay constant for product $j$. The activity $A_{j}$ of $j$, as a function of $X$, is

$$
A_{j}(X)=N_{j}(X) \lambda_{j}
$$

At a point $p$, a distance $d$ outside the slab, the flux $\phi_{j}(X)$ of photons resulting from $A_{j}(X)$ is

$$
\phi_{j}(X)=\left[A_{j}(X) \exp \left(-\mu_{j} X\right)\right] / 4 \pi(X+d)^{2},
$$

where $\mu_{j}$ is the absorption coefficient for the radiation. The radiation dose rate $D_{j}(X)$ due to $A_{j}\left(x^{\prime \prime}\right)$ is ${ }^{1}$

$$
D_{j}(X)=\text { const } \phi_{j}(X) E_{j},
$$

where $E_{j}$ is the energy of the photons. The total dose rate at a point $p$ due to all activity from product $j$ distributed along the incident beam path is obtained by integration:

$$
D_{j}=\left\{\operatorname{const} I_{0} \Sigma_{j} E_{j}\left[1-\exp \left(-\lambda_{j} t_{B}\right)\right] \exp \left(-\lambda_{j} t_{c}\right)\right\} \int_{0}^{x_{\max }}\left\{\left[\exp \left(-\Sigma_{t}+\mu_{j}\right) X\right] /(X+d)^{2}\right\} d X,
$$

where $X_{\max }$ is the smaller quantity of the slab thickness and the range of the incident protons in the slab material. In actual calculations, the integration does not need to extend to the range of several hund red Mev protons because of the exponential attentuation of the gamma radiation in the material. The analytical evaluation of the integral yields a slowly converging infinite series; therefore, numerical integration is used to evaluate $D_{j}$. For the total dose rate at a given point $p$, the $D_{i}$ 's for all the spallation products must be evaluated.

\section{DESCRIPTION OF THE PROGRAM}

The program determines the dose rate, for specified bombardment and cooling times, at the exposed surface of the irradiated material, at a distance of $10 \mathrm{~cm}$ from the surface, and at a distance of $100 \mathrm{~cm}$.

Initially, the program reads and stores all the desired bombardment and decay times and the required information about each spallation product. The integral in Eq. (7) depends only on the formation cross section for a given species, the absorption coefficient for the radiation, and the distance from the surface. As the information about each spallation product is read and stored, the program evaluates this integral for the three distances and stores these in a two-dimensional array. For each bombardment and decay time the remainder of Eq. (7) is computed for each spallation product and is also stored in a two-dimensional array.

Finally, the total dose rate at each distance from the slab surface is calculated by taking the sum of the products of the appropriate elements from each array. In this manner the redundant parts of Eq. (7) are computed only once. The program prints out the total dose rates, as well as

\footnotetext{
${ }^{1}$ M. Honda and D. Lal, Phys. Rev. 118, 1618 (1960).
} 
the contribution of each spallation product to the total dose, for each set of bombardment and decay times. The FORTRAN listing for the main program is given in Appendix I.

The numerical evaluation of the integral in Eq. (7) is performed by a function subroutine AINT. The total range of the impinging particle in the slab material is divided into a specified number of layers. The contribution to the total dose is then calculated for each layer; the source is assumed to be concentrated at the midpoint of the layer. The total dose is then the sum of the individual layers. When the depth of the layer becomes great enough that the contribution is less than $0.1 \%$ of the contribution from the first layer, the sum is terminated and the value returned to the program. If very thin layers are chosen, the denominator of the integral is not well behaved for the case of the surface dose. To avoid this singularity in the function, the denominator is restricted to a lower limit of unity. This approximation leads to a consistent value of surface dose as a function of layer thickness. The FORTRAN listing for the AINT function is given in Appendix II.

\section{USE OF THE PROGRAM}

The first card of input data for each case contains four fields. The first three fields are eight columns each and are, in order, the total range of the incident particle in centimeters or the slab thickness (the smaller quantity is entered), the macroscopic total cross section for the particle in reciprocal centimeters, and the number of divisions of the range desired for the numerical integration. The decimal point is assumed to be at the right-hand edge of each field unless specifically entered. The final field is 60 columns and may contain any alphanumeric information to identify the calculation. This information will be printed at the top of the first output page for each case. In practice, it has been found convenient to make the number of range divisions about the same as the range so that each layer in the integration is about $1 \mathrm{~cm}$ thick.

The next card contains the desired bombardment and decay times. These times are entered in pairs with up to four pairs per card, making a total of eight fields per card. The fields are eight columns each and are successively bombardment time and decay time in hours. The program will accept up to 20 of these cards, or a total of 80 bombardment-decay-time pairs. The final card of this type must be followed by a card containing a -1 in the first eight columns.

The next cards contain the information about the individual spallation products. There is one card for each product. The data for these cards are summarized in Table 1 and discussed in more detail in the next section. The program will accept up to 89 of these cards. The last card must be followed by a card containing a -1 in the first eight columns.

The above cards constitute a complete case. As many complete cases as desired may be included in the input deck. A sample input sheet for a simple case is shown in Fig. 1, and the resulting output is shown in Fig. 2. 
650 DATA SHEET

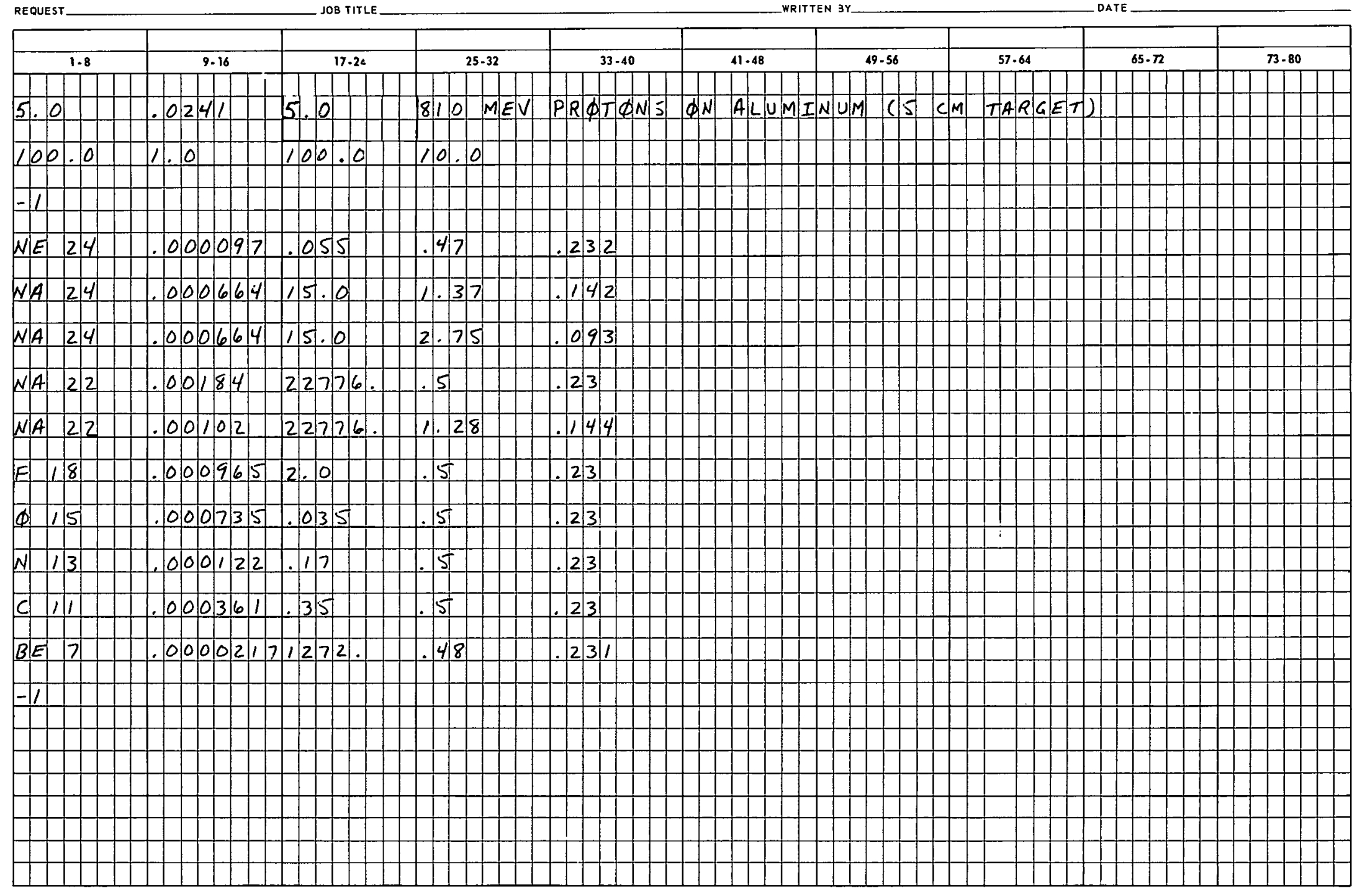

Fig. 1. Sample Input Dato Sheet. 
ACTIVATIOV MOSE RATE CALCULATION FOR 8ID MEV PROTONS ON ALUMINUM I5 CM TARGETI

SOMEARDMENT TIME H I.DOE D2

COOLING TIME $\#$ I .DOE SO

SURFACE DOSE PATE \#3.86E 03

DOSE RATE AT IO CM \# $3.48 E$ OI

DOSE RATE AT I MFTFR \#8.92E-0I
ALL TIMES IN HOURS

ALL DOSE RATES IN R/HR-MICROAMPERE OF INCIDENT BEAM

\begin{tabular}{|c|c|c|c|c|c|c|c|}
\hline PRODUCT & $M \times S(1 / C M)$ & HALFL IFE & $E G(N E V)$ & MUABS & SURFACE DOSE & DOSE AT $10 \mathrm{CM}$ & DOSE AT. I M \\
\hline NF 24 & 0.8070970 & $5.50 E-02$ & 0.470 & 0.232 & $1.79 E-04$ & $2.76 E-06$ & $3.68 E-08$ \\
\hline NA 2.4 & $\therefore .0006640$ & $1.50 \%$ DI & 1.370 & 0.142 & $1.10 E 03$ & $1.81 \mathrm{E} 01$ & $2.48 \mathrm{E}-\mathrm{D} 1$ \\
\hline NA 24 & C. 90066411 & $1.50 E \quad 01$ & 2.750 & 0.093 & $2.32 E \quad 03$ & 4.0OE DI & $5.53 \mathrm{E}-01$ \\
\hline NA 22 & 0.00184110 & $2.28 E \square 4$ & 0.500 & 0.230 & $3.26 \mathrm{E} 00$ & $5.03 E-02$ & $6.72 F-04$ \\
\hline NA 22 & 0.0010200 & $2.28 E \quad 04$ & $! .280$ & 0.144 & $5.05 E 00$ & $8.33 E-02$ & $1.14 E-03$ \\
\hline F 18 & 1. 0009650 & 2.0OE TO & 0.500 & 0.230 & $3.99 \mathrm{E} \mathrm{O2}$ & $6.14 \mathrm{E} \quad 0 \mathrm{O}$ & $8.21 E-02$ \\
\hline 015 & 0. 0007350 & $3.50 E-02$ & 0.500 & 0.230 & $1.08 E-76$ & $1.67 E-08$ & $2.23 E-10$ \\
\hline$N 13$ & 0.0001220 & $1.70 E-01$ & $0.5 n 0$ & 0.230 & $1.21 \mathrm{~F} 00$ & $1.86 \mathrm{E}-02$ & $2.49 \mathrm{~F}-04$ \\
\hline$C \quad 11$ & T. .0003610 & $3.50 E-\pi 1$ & 0.500 & 0.230 & $2.91 \mathrm{E} 01$ & $4.49 E-01$. & $5.99 E-03$ \\
\hline BE 7 & 0.0000217 & $1.27 E \quad 03$ & 0.480 & 0.231 & $6.44 E-01$ & $9.92 E-03$ & $1.33 E-04$ \\
\hline
\end{tabular}

Fig. 2. Sample Output Sheet. The output shown here resulted from the first case of the input data shown in Fig. 1. 
Table 1. Summary of Data on Spallation-Product Cards

\begin{tabular}{|c|c|c|c|}
\hline Field & Columns & Entry & Units \\
\hline 1 & $1-6$ & $\begin{array}{l}\text { Alphanumeric identification } \\
\text { of product }\end{array}$ & \\
\hline 2 & $9-16$ & $\begin{array}{l}\text { Macroscopic production } \\
\text { cross section }\end{array}$ & $\mathrm{cm}^{-1}$ \\
\hline 3 & $17-24^{\circ}$ & Half-life & hr \\
\hline 4 & $25-32$ & Encrgy of gamma ray & Mev \\
\hline 5 & $32-40$ & $\begin{array}{l}\text { Absorption coefficient for } \\
\text { gamma ray }\end{array}$ & $\mathrm{cm}^{-1}$ \\
\hline
\end{tabular}

\section{PREPARATION OF INPUT DATA}

The utility of the program is obviously depend ent on a comprehensive set of spallation-product data. This entails a literature search from which a compilation of production cross sections for the spallation products is obtained. Extremely short and very long half-lives may be deleted. In the work for the ORNL $\mathrm{Mc}^{2}$ Cyclotron, half-lives less than $1 \mathrm{~m}$ in were not included; the input format of the program (in its present form) limits half-life values to $10^{8} \mathrm{hr}$ or about $11,500 \mathrm{yr}$. For products which decay to more than one final state, each branch is treated as a separate product with the production cross section prorated. Similarly, isomeric states are handled by treating each transition as a separate spallation product. Positron emitters are treated as $0.5-\mathrm{Mev}$ gamma emitters with the production cross section doubled.

Examples of spallation-product data sets are illustrated in 'lables 2 to 5 where data for the materials most extensively used in cyclotron construction are tabulated. The cross sections are for $800 \mathrm{Mev}$ incident energy and in most cases can be used for $500 \mathrm{Mev}$ to $1 \mathrm{Gev}$ without incurring large errors. The cross-section data were obtained mainly from refs 1 to 5 . The linear absorption coefficients were obtained by interpolating a table of linear absorption coefficients. ${ }^{6}$

The program can be used for high-energy neutrons as well as for charged particles. The main limitation is the availability of complete sets of spallation cross-section data. With appropriate assumptions the results of the computer calculation can be used to estimate residual radiation levels for oblique incidence and for distributed fluxes of incident particles. Examples of application of the program are presented in ref 7 .

\footnotetext{
${ }^{2}$ P. Benioff, Phys. Rev. 119, 316 (1960).

${ }^{3}$ G. Rudstam, E. Bruninx, and A. C. Pappas, Phys. Rev. 126, 1852 (1962).

${ }^{4} \mathrm{~J}$. Hudis et al., Phys. Rev. 129, 434 (1963).

${ }^{5}$ E. Bruninx, High-Energy Nuclear Reaction Cross-Sections. I, CERN 61-1 (Jan. 16, 1961); High-Energy Nuclear Reaction Cross-Sections. II, CERN 62-9 (Feb. 15, 1962).

${ }^{5}$ Samuel Glasstone, Principles of Nuclear Reactor Engineering, p 78, D. Van Nostrand, 1955.

${ }^{7}$ C. B. Fulmer, K. S. Toth, and M. Barbier, "Residual Radiation Studies for Meson Factories," to be published in Nuclear Instruments \& Methods.
} 


\section{ACKNOWLEDGMENT}

The spallation-product cross-section data of Tables 2 to 5 were compiled from a literature search by K. S. Toth.

Table 2. Spallation-Product Data for $800-$ Mev Protons in Carbon The data here and in Tables 3 to 5 are in the form of the computer output. MXS(1/CM) is the macroscopic production cross section in $\mathrm{cm}^{-1}$; HALF LIFE is the half-life in hours; EG(MEV) is the energy in Mev of the emitted gamma; MUABS is the linear absorption coefficient in $\mathrm{cm}^{-1}$ of the slab material for the emitted gamma. In the column labeled HALFLIFE the number is listed as a coefficient times a decimal exponent.

$\begin{array}{lllll}\text { PRODUCT } & \text { MXS(I/CM) } & \text { HALFLIFE } & \text { EG(MEV) } & \text { MUABS } \\ \text { C-11 } & 0.0058200 & 3.3 \text { CE-O } & 0.500 & 0.18 \\ \text { C-10 } & 0.0006220 & 5.50 E-03 & 0.500 & 0.18 \\ \text { C-10 } & 0.0003110 & 5.50 E-03 & 0.500 & 0.18 \\ \text { BE-7 } & 0.0001300 & 1.27 E 03 & 0.480 & 0.18\end{array}$

Table 3. Spallation-Product Data for 800-Mev Protons in Aluminum

\begin{tabular}{|c|c|c|c|c|}
\hline PRODUET & $M \times S(1 / C M)$ & HALFL IFE & $E G(M E V)$ & MUABS \\
\hline NE 24 & 0.0000970 & $5.5 \square E-\square 2$ & 0.470 & 0.232 \\
\hline$N \wedge 24$ & ก. $000664 \Gamma$ & $1.50 \mathrm{~F} \quad 01$ & 1.370 & 0.142 \\
\hline$N A 24$ & 1:000664 ? & $1.50 \mathrm{~F}$ ○I & 2.750 & 0.093 \\
\hline NA 22 & .0018400 & $\therefore .28 \mathrm{E} \quad 74$ & 0.500 & 0.230 \\
\hline NA 22 & 0.0010200 & $2.28 E \quad 04$ & 1.280 & 0.144 \\
\hline$F \quad 18$ & . . 0009650 & 2.0OE DO & 0.500 & $0.23]$ \\
\hline 015 & 0.0007350 & $3.50 E-02$ & 0.500 & 0.230 \\
\hline$N \mid 3$ & 0.00101220 & $1.70 E-01$ & $0.501]$ & 0.230 \\
\hline$C \quad 11$ & 0.0003610 & $3.50 E-01$ & 0.500 & 0.230 \\
\hline BE $?$ & ก. กแกก217 & $1.27 E \quad 03$ & 0.480 & 0.231 \\
\hline
\end{tabular}


Table 40 Spallation-Product Data for 800-Mev Protons in Iron

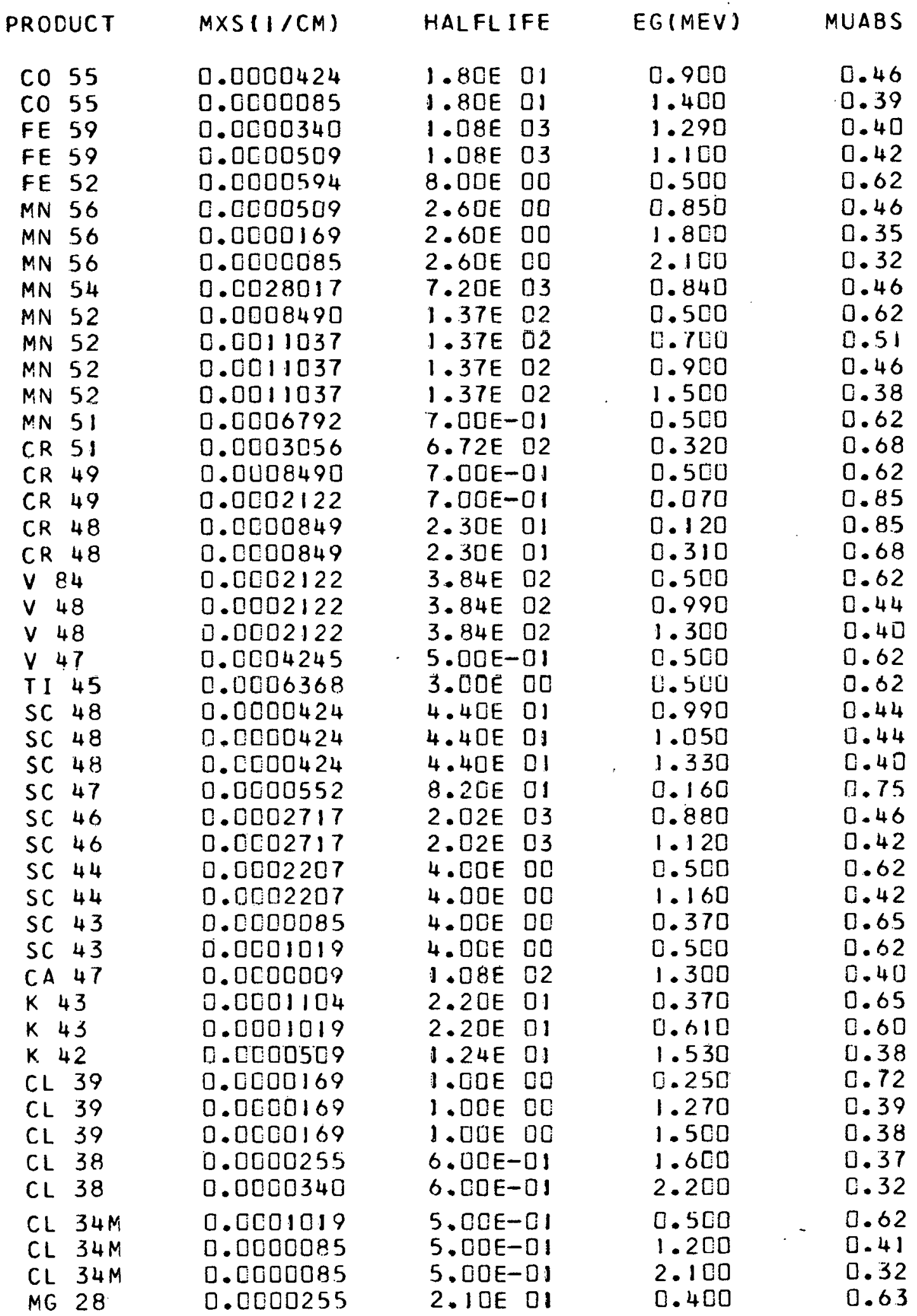


Toble 4. (continued)

$\begin{array}{ll}\text { MG } & 28 \\ \text { MG } & 28 \\ \text { MG } & 28 \\ \text { NA } & 24 \\ \text { NA } & 24 \\ \text { NA } & 22 \\ \text { NA } & 22 \\ \text { BE } & 7\end{array}$

\begin{tabular}{|c|c|}
\hline 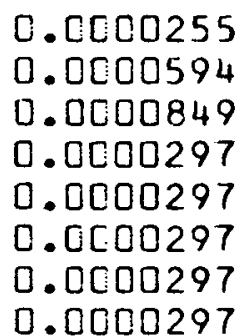 & $\begin{array}{l}2.10 E \\
2.10 E \\
2.10 E \\
1.50 E \\
1.50 E \\
2.28 E \\
2.28 E \\
1.27 E\end{array}$ \\
\hline
\end{tabular}

0.950

0.46

1. 350

0.40

0.030

0.95

1. 380

0.39

2.750

C. 30

0.500

0.62

1.280

0.35

0.480

0.62

Table 5. Spallation-Product Data for 800-Mev Protons in Copper

\begin{tabular}{|c|c|c|c|c|c|}
\hline \multicolumn{2}{|c|}{ PRODUCT } & $M \times S(1 / C M)$ & HALFLIFE & $E G(M E V)$ & MUABS \\
\hline $\mathrm{CU}$ & 64 & C.00] 87C0 & 1.30E 01 & 0.500 & 0.7 \\
\hline $\mathrm{Cu}$ & 62 & 0.0037400 & 1.7OE-OI & 0.500 & \\
\hline $\mathrm{Cu}$ & 61 & 0.0011900 & $3.30 E 00$ & 0.500 & \\
\hline $\mathrm{CU}$ & 60 & 0.0002970 & 4. .00E-01 & C. 500 & \\
\hline $\mathrm{CU}$ & 60 & D. CCOJ 270 & 4. $00 E-01$ & 1.300 & \\
\hline $\mathrm{CU}$ & 60 & 0.0000850 & 4. $.00 E-01$ & 1.760 & \\
\hline$N I$ & 65 & 0.0000034 & $2.60 E \quad 00$ & 1.110 & \\
\hline $\mathrm{NI}$ & 65 & 0.0000068 & $2.60 E$ CO & 1.480 & 0.2 \\
\hline NI & 57 & 0.0000340 & $3.60 \mathrm{E} 01$ & $0.5[0$ & 0. \\
\hline NI & 57 & 0.0000340 & $3.60 E$ OI & 1.370 & 0. \\
\hline NI & 57 & 0.0000042 & $3.60 E$ OI & 1.900 & 0.3 \\
\hline $\mathrm{CO}$ & 60 & 0. 0000340 & $1.65 E 00$ & 0.070 & 1 \\
\hline $\mathrm{CO}$ & $60 M$ & 0.0003400 & $1.80 E-01$ & 0.060 & 1.1 \\
\hline $\mathrm{CO}$ & $O O M$ & 0.0003400 & $1.80 E-01$ & 1.170 & 0.4 \\
\hline $\mathrm{CO}$ & $60 M$ & 0.0003400 & 1.80E-01 & 1.330 & \\
\hline $\mathrm{CO}$ & 60 & 0.0003400 & $4.65 E \quad 03$ & 1.170 & \\
\hline $\mathrm{CO}$ & 60 & 0.0003400 & $4.65 E \quad 03$ & 1.330 & \\
\hline $\mathrm{CO}$ & 58 & 0.0006800 & $1.70 E \quad 03$ & 0.500 & \\
\hline $\mathrm{CO}$ & 58 & 0.0020400 & 1.70E 03 & 0.800 & \\
\hline $\mathrm{CO}$ & 56 & 0.0001700 & $1.85 E \quad 03$ & 0.500 & \\
\hline $\mathrm{CO}$ & 56 & 0.0004200 & $1.85 E \quad 03$ & 0.850 & \\
\hline $\mathrm{CO}$ & 56 & 0.टतC2970 & $1.85 E \quad 03$ & 1.200 & \\
\hline $\mathrm{CO}$ & 56 & 0.0002120 & $1.85 \mathrm{E} 03$ & 2. $[000$ & \\
\hline $\mathrm{CO}$ & 55 & 0.0002100 & $1.80 \mathrm{E} \mathrm{O1}$ & 0.500 & \\
\hline $\mathrm{CO}$ & 55 & 0.0001700 & $1.80 E$ OI & 0.900 & \\
\hline FE & 59 & 0.0000250 & 3. $.08 E \quad 03$ & 1.100 & \\
\hline FE & 59 & 0.0000255 & 1.08E 03 & 0.300 & \\
\hline FE & 52 & 0.0000170 & 8.DOE 00 & 0.500 & \\
\hline MN & 56 & 0.0002550 & $2.60 E \quad 00$ & 0.850 & \\
\hline MN & 56 & 0.0000850 & $2.60 E 00$ & $1.8 C 0$ & \\
\hline$M N$ & 56 & 0.0000510 & $2.60 E 00$ & 2.100 & \\
\hline$M N$ & 54 & 0.0008490 & $7.20 \mathrm{E} \quad 03$ & 0.840 & \\
\hline$M N$ & $52 M$ & 0.0003400 & $3.00 E-01$ & 0.500 & \\
\hline
\end{tabular}


Table 5. (continued)

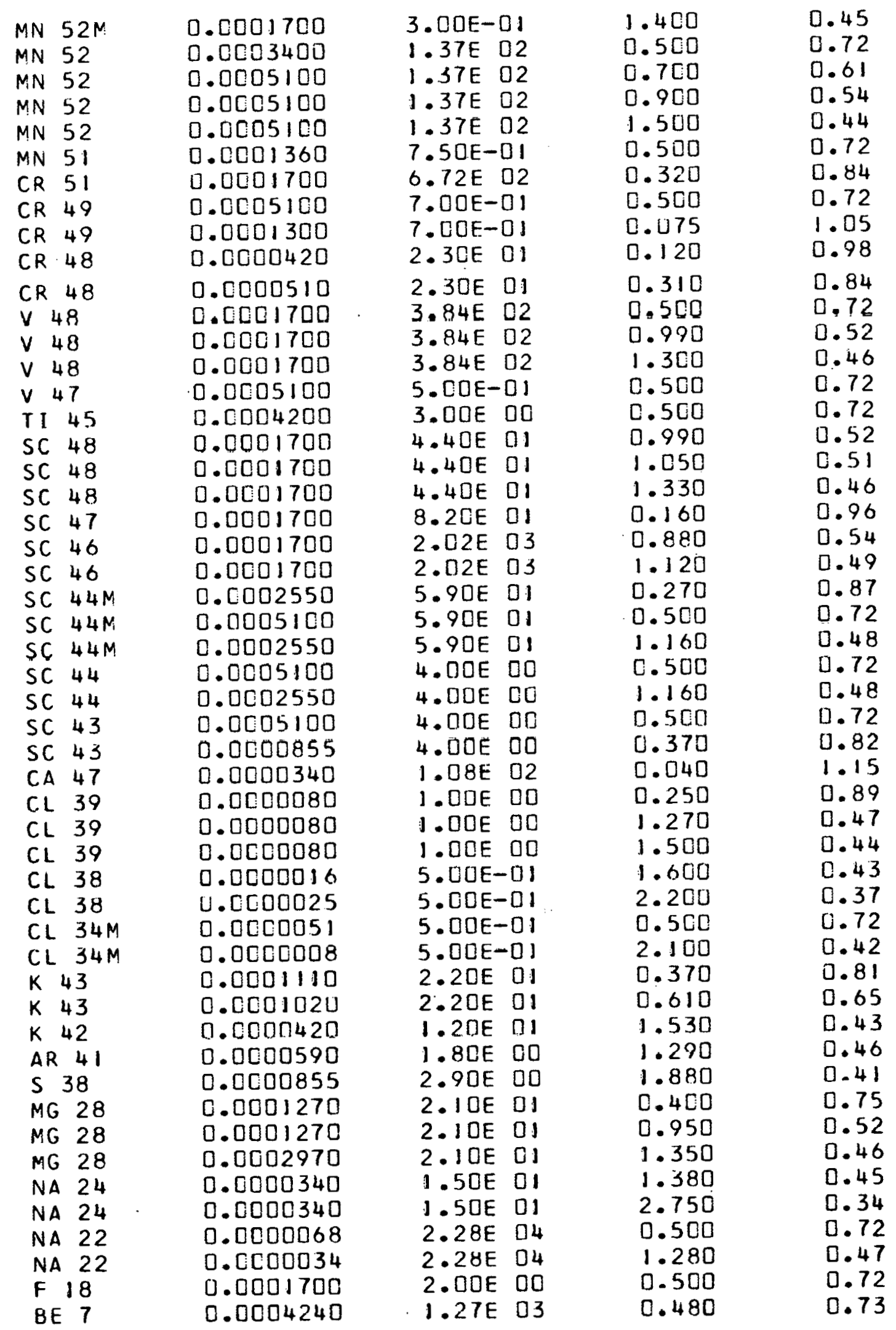




\section{Appendix 1}

\section{FORTRAN LISTING FOR MAIN PROGRAM}

C PROSRAT: FOR COMPUTING ACTIVATION DOSE RATES

DIMENSIOV TB(84), TD(84), PROD(90), SIGMAJ(90), HALFT (90), EGAMMA(90), ICARSJ $(90), D(3)$, TI TLE (ID), SUNDI 3$)$,

$2 F 1(90,3), F 2(90,84), D O S E(9), 3)$

11 RFADIINPUTTAPEIO, 41 , RANGE, SIGTOT, RIIV, TITLE NI $H-3$

$12 N|\# N|+4$

$N 2 H N I+3$

READINPUTTAPEIO, $12,(T E(N), T D(N), N \# N 1, N 2)$

IF(TBINI) $13,13,12$

$1.30(1)$ H. 0.0

ก(2) \#10.0

D(3) $\$ 1 \mathrm{COC} . \mathrm{C}$

DO $171 \mathrm{~J} \| 1,3 !$

14 READINPUTTAPEIC, 43,PROD(J),SIGMAJ (J),HALFT(J), EGAMMA (J), $(\wedge B S J(J)$ IF(SIGMAJ J J) $20,20,15$

$15 \mathrm{NJHJ}$

$0016 \mathrm{~K}: 11,3$

$16 \mathrm{FI}(J, K)$ HAINT(SIGTOT,CABSJ(J), D(K), RANGE, RDIV)

17 DOIOIHI, NI IFITB(I) $191,191,18$

$18 \mathrm{VI} H \mathrm{I}$

ARGI HEXPF (-C.693* TD(I) /HALFT(J))

ARG, H1.0-EXPF(-0.693*TB( I)/HALFT(1))

$19 \mathrm{~F} 2(\mathrm{~J} .11 \%(3.86 \mathrm{ES}) * \mathrm{EGAMMA}(\mathrm{J}) * S I G M A J(\mathrm{~J}) * A R G I * A R G 2$

IQI CONTINUE

20 $\mathrm{NO} 22 \mathrm{I} \# 1, \mathrm{NI}$

$002 \mid K A 1,3$

SUMD $(K) \# D .0$

DOSIJ J $1, \mathrm{NJ}$

DOSE $(J, K) \# F 2(J, I) \# F I(J, K)$

$21 \operatorname{SUMN}(K) \# \operatorname{SUMD}(K)+D O S E(J, K)$

WR I TEOUITPUTTAPE9, 44, TITLE,TB(I),TD(I), (SUMD (L) . L\#1,3)

WP.I TEOUTPUT TAPE), 45, (PROD (L), SIGMAJ (L), HALFT (L), EGAMMA (L),

ICABSJ (L), (DOSE (L, LKK),LK\#I, 3),L\#I,NJ)

3.2 CONTI VUE

G0TOII

41 FORMAT (3FB.0, ITIAS)

4. FORMAT(BF 8.0$)$

4.3 FOIRMAT(A6, 2X, $4 F 8.0)$

44 FURMAT( IH1.2X3/HACTIVATION DOSE RATE CALCULATION FOR,

$110 A 6 / 1 H O / 1 H, 4 \times 18 H B O M B A R D M E N T$ TIME \#IPE. 2.2 ,

$218 \times 18 H A L L$ TIMES IN HOURS/IHO, 4XI4HCOOLING TIME \#E9.2/

$31110.4 \times 19 H S U R F A C E$ UOSE RATE HE9.2, $17 \times 51$ HALL DOSE RATES IN R/HR-MICR 4OAMPERE OF INCIDENT BEAM/IHO, $4 \times 2$ OHIDOSE RATE AT IO CM HE9.2/

$5 I H C, 4 \times 22 H I D O S E$ RATE AI I METER HE9.2)

45 FORMAT ( IHD/ IHD, $4 \times 7$ HPRODUCT, $5 \times 9 H M \times 5(1 / C M), 5 \times 8 H H A L F L I F E, 5 \times 7 H E G(M E V)$, I5X5HMUABS, $5 \times 12$ HSURFALE DOSE, $5 \times 13 H D O S E$ AT ID CM, 5XIIHDOSE AT I M/I $2(1 \mathrm{H}, \Xi \times A 6, D P F I 4.7,4 \times \mid P E ? .2$, OPFII.3,FI1.3,7XIPE9.2,8XE?.2,8XE9.2))

ENC $(1,1, \Pi, 0,0,0, \cup, \cup, 0,0,0,0,0, U, \cup)$ 
Appendix II

FORTRAN LISTING FOR AINT FUNCTION

FIJNCTIONAINT(SIGTOT, CABSJ,D.R, ROIVI

DIMENSIONG(500)

XINCH? /RDIV

PINTHOD

NOIVHIRIIV

ASSIG:STTOOK

DO32I II, NDIV

FI-TGI:I

$X ! I F L T I-0.5) * X I V C$

GOTOK, $(20,30)$

$25 \quad I F(x+n-1.0121,22,22$

21 DEVOM 1.0

GOTO3I

22 ASSIGN3OTOK

3] DEVOM $4(X+D) * 2$

31 GII) HEXPF (-X * SIGTOT+CABS.1)) /DENOM

IF( (G(I)/G( I) )-D.0DI $133,32,32$

32 PINTHPINT+G(I)

3.3 AIVTHPIVT*XINC.

RETURN

$\operatorname{ENO}(1,1,0,0,0,0,3,0,0,0,0,0,0,0,0)$ 


\section{ORNL-3554}

UC. 20 - Controlled Thermonuclear Processes TID.4500 (26th ed.)

\section{INTERNAL DISTRIBUTION}

1. Biology Library

2-4. Central Research Library

5. Reactor Division Library

6-7. ORNL - Y-12 Technical Library

Document Reference Section

8-27. Laboratory Records Department

28. Laboratory Records, ORNL R.C.

29-40. J. B. Ball

41. L. Blumberg

42. E. Eichler

43-54. C. B. Fulmer

55. F. T. Howard

56. C. E. Larson

57. R. S. Livingston

58. J. A. Martin
59. E. Newman

60. M. J. Skinner

61. A. H. Snell

62. J. A. Swartout

63. J. W. Wachter

64. A. M. Weinberg

65. H. Wright

66. A. Zucker

67. A. M. Clogston (consultant)

68. B. L. Cohen (consultant)

69. M. Deutsch (consultant)

70. D. L. Judd (consultant)

71. L. J. Rainwater (consultant)

72. J. A. Wheeler (consultant).

\section{EXTERNAL DISTRIBUTION}

73. Research and Development Division, AEC, ORO

74-705. Given distribution as shown in TID-4500 (26th ed.) under Controlled Thermonuclear Processes category ( 75 copies - OTS) 